\title{
The Wage Impact on the Net Value-Added in the Agricultural Sector
}

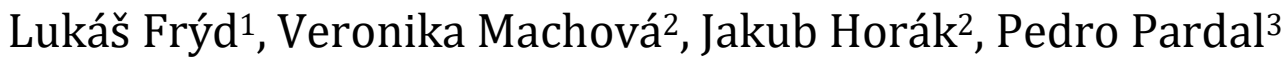 \\ ${ }^{1}$ University of Economics, Faculty of Informatics and Statistics, Czech Republic \\ 2Institute of Technology and Business in České Budějovice, School of Expertness and \\ Valuation, Czech Republic \\ 3Polytechnic Institute of Setúbal, Department of Accounting and Finance, Portugal
}

\begin{abstract}
Entrepreneurship in the area of agriculture is subject to various factors, such as nature risks (hydrologic, pests and diseases) or recently notable economic hazards with disastrous consequences for a lot of enterprises. A grave issue is, for example, a vast wage rise to which the agricultural sector fails to respond, thus threatening the existence of these companies. The article aims at analysing the way wages influence the net value-added (NVA) in the agricultural sector of V4 and identifies components with a significant impact on NVA thereof. The data set from 2004-2017 of V4 provides the relevant data, using statistical methods - Maddala-Wu Test, Akaike Information Criterion and Engle and Granger two-step method to detect the relation between the average and minimum wage of NVA. The average wage increase positively influences NVA, as contrasted with minimum wages harming MVA.
\end{abstract}

Key words: market value-added (MVA), average and minimum wage, agriculture, performance and productivity of the enterprise

\section{Introduction and Literary Research}

The agricultural sector is at risk abiding by important decisions of social-individual character due to factors concerning weather, pests and diseases or economic issues such as changes in market conditions or government policies relating to the primary sector (Iyer et al., 2018), considering the artificial intelligence development and follow-up effective strategy as a possible solution to predict these risks (Stehel, Horák and Vochozka, 
2019). Vrbka and Rowland (2020) observe in artificial neural networks a variety of applications in all spheres of life, mostly given their ability to perceive behavioural archetypes and learning abilities, leading to correctly predicting future developments and making crucial decisions.

According to Aleknevicien, Stareviciut and Aleknevicien (2018) earlier EU member states more effectively manage the risk reduction to agricultural enterprises. Employers face hazards and follow-up problems by counter-balancing missed opportunities and lost employees, jobs such as managers, qualified farmers, foresters and fishers being at a higher risk of leaving, as contrasted with less-mobile professions like technical workers, technical experts, professionals, associated professional workers, business workers, mechanics, machine maintenance workers and sale and after-sale workers (Bachmann et al., 2020). The development and application of information and computing technologies have highly contributed to changing the labour-market structure in the last four decades, mostly in fixed-routine positions (Bachmann, Cim and Green, 2019). Some experts reflected on this influence as unfavourable regarding holding down steady jobs, fearing automation trimming the workforce. On the contrary, Autor (2015) considers the development in robotics and artificial intelligence as an opportunity to offer comparative advantages of human capital.

Agriculture must take into account a rather uncomfortable situation of the respective enterprises resulting from enormous economic influences, often pushed to purchase a land of their former competitors, which leads to reducing numbers of their employees (Beckers et al., 2018). The European employment rate in the agrarian sector decreases, the trend being the most apparent in companies focused on livestock, except for Spain and The Netherlands (Houstiou et al., 2020). Bojnes and Ferto (2020) observe the integration of agricultural corporations into developmental activities in Slovenia and Hungary, demonstrating the overwhelming dominance of small-scale organizations within these activities including without limitations Hungary. McKillop, Heal and Kinsela (2018) classify agrarian enterprise owners by age, indicating a relative scarcity of fresh businessmen involved in agriculture throughout Europe. Duesbergová, Bogue and Renwick (2017) point out the critical importance of supporting new farmers, as seasoned producers without successors are less productive and open to new environmental methods. Cassidy and McGrath (2015) observe the trend of young people from rural areas of Ireland to migrate outside their home community. Bernues et al. (2011) see the same decline in fresh farmers in the Mediterranean area. The fiscal policy of the European Union responds to the situation by giving loans with different maturity deadlines or grants to follow young people's tendency towards long-term planning and help them with entrepreneurship (Davis, Caskie and Wallace, 2013). Work and business in the agricultural sector are not attractive for the youth, the trend needing a change to ensure the sustainability of the primary sector.

Acemoglua and Autor (2011) observe the decline in real wages for unqualified posts including without limitations unskilled men. Thanks to rapid technological development, the machinery can substitute workers with secondary education in various tasks. Abbritti 
and Fahr (2013) analyse the relationship between the wage increase and creating job vacancies, arguing that an enormous wage increase in OECD results in job vacancy decline. Deutch and Himmelreicher (2020) state that high average wages in the national economy pose a risk to low-income jobs, leading to threatening the existence of agricultural companies, as such low wages make workers leave the primary sector for missed opportunities (Spicka et al., 2019). Kühl, Flach and Gauly (2019) seek the correlation between hourly salaries and the value of data of agrarian companies, stating that greater inputs generate higher wages. Batyr et al. (2019) argues that grants provided to agricultural corporations in Germany and France significantly affect worker marginal income. Braun et al. (2019) assess the influence of the imposition of minimum wages on the employment rate, considering the implemented government measures leading to stabilizing the labour market as ineffective. Low-wage sector thereby incurs risks of the negative impact on the employment rate. Rather unclear consequences of inadequatewage influences require further research.

The article focuses on analysing the influence of wages in the agricultural sector of $\mathrm{V} 4$ on net value added (NVA) and identifying specific factors affecting NVA thereof. The indicator helps measure the contribution of the personnel capital to the performance and productivity of the enterprise, formulating two plausible hypotheses. The first one concerns the average wages swaying NVA, whereas the second presumes the minimum income impacting NVA.

The hypotheses are as follows:

Hypothesis $1 \mathrm{H} 0$ : the average wages do not influence NVA vs. H1: the average wage influences NVA,

Hypothesis $2 \mathrm{H0}$ : the minimum wages do not influence NVA vs. H1: the minimum wages influence NVA.

\section{Data and Model}

The research analyses annual data of four countries from 2004-2017: the Czech Republic, Slovakia, Poland and Hungary, using variables such as Net Value-Added (NVA), Wages (W), Total Assets (TA) and Minimum Wage (MW) in EUR and Total Utilized Agricultural Area (TUAA) in hectares. All these variables relate to the Total Employment Rate assessed by $A W U^{1}$, designated per worker by lowercase letters. The data were amassed from FADN $^{2}$ and Eurostat ${ }^{3}$ databases.

The analysis follows the intensive form of the production function with NVA being a dependent variable, while TUAA approximates the land factor of production, TA doing the same to the capital: both activities relate to workers. The analysed formula is as follows:

\footnotetext{
${ }^{1}$ More about variables on https://ec.europa.eu/agriculture/rica/methodology3_en.cfm.

${ }^{2} \mathrm{https}$ ://ec.europa.eu/agriculture/rica/.

${ }^{3} \mathrm{https}$ ://ec.europa.eu/eurostat.
} 


$$
n v a_{i t}=\alpha_{i}+\beta_{1} \text { tuaa }_{i t}+\beta_{2} t a_{i t}+\beta_{3} w_{i t}+\beta_{4} m w_{i t}+\epsilon_{i t}
$$

Where $i=1,2,3,4$ represents individual states in time $t$, for $t=1,2, \ldots, 14$. Parameter $\alpha_{i}$ presents unobserved heterogeneity of country $i$. A random element is presumed to $\epsilon_{i t} \sim$ $\operatorname{iid}\left(0, \sigma^{2}\right)^{4}$. Unobserved heterogeneity results, for example, from different socio-political situations of a specific country.

\section{Empirical part}

Maddala-Wu method from 1999 tested unit roots for variables in equation (1), while Akaike information criterion estimated the delay. Table 1 proposes the test results.

Tab. 1: Manddala-Wu unit root test

Source: Authors.

\begin{tabular}{|l|r|r|}
\hline Variable & \multicolumn{1}{|c|}{ t-test } & \multicolumn{1}{|c|}{-value } \\
\hline$n v a$ & 0.3930 & 1 \\
\hline tuaa & 4.116 & 1 \\
\hline$t a$ & 0.077 & 1 \\
\hline$w$ & 0.131 & 1 \\
\hline$m w$ & 0.019 & 1 \\
\hline
\end{tabular}

The table suggests that neither variable can reject zero hypotheses on the presence of the unit root, which leads to testing first differences on the unit root presence. Table 2 illustrates the achieved results.

Tab. 2: Manddala-Wu unit root test - the first difference

Source: Authors.

\begin{tabular}{|l|r|r|}
\hline Variable & \multicolumn{1}{c|}{ t-test } & p-value \\
\hline$\Delta n v a$ & 98.527 & 0.000 \\
\hline$\Delta$ tuaa & 41.544 & 0.000 \\
\hline$\Delta t a$ & 56.475 & 0.000 \\
\hline$\Delta w$ & 50.628 & 0.000 \\
\hline$\Delta m w$ & 42.699 & 0.000 \\
\hline
\end{tabular}

\footnotetext{
${ }^{4}$ iid- independent and identically distributed.
} 
Now we can reject zero hypotheses in behalf of alternative hypotheses predicting the integration of all variables in the order of one.

The testing on the presence of the co-integration relation follows Engle and Granger twostep method from 1987, the first step calculating equation (1) by within estimator (e.g. Woolridge, 2010). Table 3 depicts the computed results. The second step deals with testing the residua from the first step on the presence of the unit root by Maddala-Wu method. Line I (1) suggests the achieved test results, revealing the possibility to reject zero hypotheses on the existence of the unit root. The residua integrate in the order of zero, showing a co-integration relation between variables from equation (1). The robust estimator by Arellan (1987) assesses the variation-co-variation matrix, while critical values by MacKinnon (1991) comprehensively evaluate t-test.

Tab. 3: Estimated equation (1) and co-integration testing

\begin{tabular}{|l|r|r|r|}
\hline Variable & Estimate & Standard deviation & p-value \\
\hline tuaa & -303.110 & 47.647 & 0.000 \\
\hline$t a$ & 0.097 & 0.031 & 0.000 \\
\hline$w$ & 2.785 & 0.211 & 0.000 \\
\hline$m w$ & -1.378 & 0.355 & 0.000 \\
\hline I(1) & 57.808 & & 0.000 \\
\hline
\end{tabular}

Source: Authors.

The estimation results from Table 3 show the average wages in the agricultural sector have a positive influence on generating the net value added; suggesting average wage increase by 1 EUR will produce NVA growth by 2.785 EUR. Significant changes in total assets per worker favourably influence NVA, when an extraordinary surge in the total asset by 1 EUR raises the dependent variable by 0.097 EUR. TUAA variable demonstrates the rise in the amount of utilized land adversely affects NVA, the reason being the analysed data set involves Poland, which presents a heterogeneous unit given its size and a large number of people employed in agriculture. Minimum wages also harm NVA, causing the minimum wage increase by 1 EUR but cutting NVA by 1.378 EUR.

\section{Discussion and conclusion}

Accepting important decisions in the agricultural sector always incurs potential risks, mostly from factors related not only to weather, diseases and pests but also to economic circumstances such as changes in market conditions, government policies towards the primary sector or other prevalent economic influences. A marked decline of fresh farmers and falling employment rate in the respective division also bring serious problems. A veritable wage explosion leads to shedding jobs, posing a considerable threat to the 
existence of agricultural enterprises, forcing poorly paid workers to leave the primary production sector.

The article mostly focused on exploring wage circumstances in agriculture with the view to analysing salaries in the respective field of V4 and their influence on NVA, identifying critical factors contributing to NVA in the agrarian section by formulating two hypotheses. The first one concerned whether the average wage radically affects NVA, while the second predicted the impact of minimum salaries on NVA. Annual data from 2004-2017 of V4, i.e. the Czech Republic, Slovakia, Poland and Hungary reflected the required information, using net value-added, total wages, total assets, minimum wages, total utilized agricultural area for variables which related to the overall employment rate. The paper proceeded from the intensive form of the production function, considering NVA as the dependent variable. Maddala-Wu method tested the unit root for variables, while Akaike information criterion estimated the delay. The testing on the presence of the cointegration relation followed Engle and Granger two-step method. The results suggested the average wage increase positively influenced NVA, generating the growth of NVA by 2.785 EUR, as contrasted to the rise in minimum wages negatively affecting NVA. In this case, the minimum wage explosion by 1 Euro results in NVA decline by 1.378 EUR. Although not necessary to interpret, other variables help verify the robust relation. The change in total assets per employee also favours NVA, while the increase in the amount of the utilized land per worker has a damaging impact on NVA. Both constructed hypotheses thereby proved true - the average and minimum payments significantly influence NVA the average wage positively, while the minimum salary sees a rather adverse impact.

The presented article identifies factors determining MVA, aiming at future research focused directly on declining employment in agriculture influenced by salaries within this sector. Of interest might also be to analyse growing agricultural subsidies compared to average wages.

\section{Acknowledgements}

The article was funded and submitted under IGA VŠE F4/34/2020 - Analysing higher moments within the time-frequency domain.

\section{Bibliography}

1. ABBRITTI, M., S. FAHR, 2013. Downward wage rigidity and business cycle asymmetries. Journal of Monetary Economics. 60(7), 871-886. ISSN 0304-3932.

2. ACEMOGLU, D., D. AUTOR, 2011. Skills, Tasks and Technologies: Implications for Employment and Earnings. Handbook of Labor Economics. 4B(4), 1043-1171. ISSN 0169-7218. 
3. ALEKNEVICIENE, V., B. STAREVICIUTE and E. ALEKNEVICIUTE, 2018. Evaluation of the efficiency of European Union farms: a risk-adjusted return approach. Agricultural Economics. 64(6), 241-255. ISSN 1805-9295.

4. ARELlANO, M., 1987. Computing Robust Standard Errors for Within-Group Estimators, Oxford Bulletin of Economics and Statistics. 431-434.

5. AUTHOR, H. D., 2015. Why Are There Still So Many Jobs? The History and Future of Workplace Automation. Journal of Economics Perspektivies. 29(3), 3-30. ISSN 0895-3309.

6. BACHMANN, R., P. BECHARA and CH. VONNAHME, 2020. Occupational Mobility in Europe: Extent, Determinants and Consequences. Ruhr Economics Papers, no. 732. 168(1), 79-108. ISSN 1572-9982.

7. BACHMANN, R., M. CIM and C. GREEN, 2019. Long-Run Patterns of Labour Market Polarization: Evidence from German Micro Data. The British Journal of Industrial Relations. 57(2), 350-376. ISSN 1467-8543.

8. BATYRA, A. et al., 2019. Changes in the Labor Market and the Rise of Early Retirement in France and Germany. German Economic Review. 20(4), 38-69. ISSN 1465-6485.

9. BECKERS, V. et al., 2018. Modelling Farm Growth and Its Impact on Agricultural Land Use: A Country Scale Application of an Agent-Based Model. LAND. 7(3). ISSN 2073-445X.

10. BERNUES, A. et al., 2011. Sustainability of pasture-based livestock farming systems in the European Mediterranean context: Synergies and trade-offs. Livestock Science. 139(1-2), 44-57. ISSN 1878-0490.

11. BOJNES, S., I. FERTO, 2020. The growth of farms: a Hungarian-Slovenian comparison. Post- Communist Economies. ISSN 1463-1377.

12. BRAUN, H. et al., 2019. Macroeconomic long-run effects of the German minimum wage when labor markets are frictional. Journals of Economics and Statistics. 240(2-3), 351-386. ISSN 0021-4027.

13. CASSIDY, A., B. MCGRATH, 2015. Farm, place and identity construction among Irish farm youth who migrate. Journal of Rural Studies. 37, 20-28. ISSN 0743-0167.

14. DAVIS, J., P. CASKIE and M. WALLACE, 2013. Promoting structural adjustment in agriculture: The economics of New Entrant Schemes for farmers. Food policy. 40, 90-96. ISSN 0306-9192.

15. DUESBERG, S., P. BOGUE and A. RENWICK, 2017. Retirement farming or sustainable growth - land transfer choices for farmers without a successor. Land Use Policy. 61, 526-535. ISSN 1873-5754.

16. DUETSCH, M., R. HIMMELREICHER, 2020. Characteristics Contributing to Lowand Minimum-Wage Labour in Germany. Journals of Economics and Statistics. 240(2-3), 161-200. ISSN 0021-4027.

17. ENGLE, R., WJ. C. GRANGER, 1987. Co-integration and error correction: representation, estimation, and testing, Econometrica: Journal of the Econometric Society. 251-276. 
18. HOSTIOU, N. et al., 2020. Employment and farmers' work in European ruminant livestock farms: A review. Journal of Rural Studies. 74, 223-224. ISSN 0743-0167.

19. IYER, P. et al., 2018. Measuring Farmer Risk Preferences in Europe: A Systematic Review. Journal of Agricultural Economics. 71(1), 3-26. ISSN 1477-9552.

20. KÜHL, S., L. FLACH and M. GAULY, 2019. Economic assessment of small-scale mountain dairy farms in South Tyrol depending on feed intake and breed. Italian Journal of Animal Science. 19(1), 41-50. ISSN 1594-4077.

21. MACKINNON, J. G., 1991. Critical values for cointegration tests, Long-Run Economic Relationship: Readings in Cointegration.

22. MADDALA, G., S. WU, 1999. A comparative study of unit root tests with panel data and a new simple test, Oxford Bulletin of Economics and statistics. 631-652.

23. MCKILLOP, J., K. HEANUE and J. KINSELLA, 2018. Are all young farmers the same? An exploratory analysis of on-farm innovation on dairy and drystock farms in the Republic of Ireland. The Journal of Agricultural Education and Extensions. 24(2), 137-151. ISSN 1750-8622.

24. SPICKA, J. et al., 2019. Approaches to estimation the farm-level economic viability and sustainability in agriculture: A literature review. Agricultural Economics. 65(6), 289-297. ISSN 1805-9295.

25. STEHEL, V., J. HORAK and M. VOCHOZKA, 2019. Prediction of institutional sector development and analysis of enterprises active in agriculture. E \& M Ekonomie A Management. 22(4), 103-118. ISSN 2336-5064.

26. VRBKA, J., Z. ROWLAND, 2020. Using Artificial Intelligence in Company Management. Lecture Notes in Networks and Systems. 84, 422-429. ISSN 23673370.

27. WOOLDRIDGE, J. M, 2010. Econometric analysis of cross section and panel data. MIT press.

\section{Contact addresses of the authors:}

Mgr. Ing. Lukáš Frýd, Faculty of Informatics and Statistics, Department of Econometrics, University of Economics, nám. W. Churchilla 1938/4, 13067 Prague 3, Czech Republic, email: xfryl00@vse.cz

Ing. Veronika Machová, MBA, School of Expertness and Valuation, Institute of Technology and Business in České Budějovice, Okružní 517/10, 37001 České Budějovice, Czech Republic, e-mail: machova@mail.vstecb.cz

Ing. Jakub Horák, School of Expertness and Valuation, Institute of Technology and Business in České Budějovice, Okružní 517/10, 37001 České Budějovice, Czech Republic, e-mail: horak@mail.vstecb.cz

Pedro Pardal, Ph.D., Department of Accounting and Finance, Business and Management School, Polytechnic Institute of Setúbal, Campus do IPS - Estefanilha - 2910-761 Setúbal, Portugal, e-mail: pedro.pardal@esce.ips.pt 